\title{
European Integration and Contemporary Idea of Europe
}

\author{
Huarong Zhang \\ Foreign Language Department \\ The Engineering \& Technical College of Chengdu University of Technology \\ Leshan, Sichuan, China \\ zhrhyq1981@163.com
}

Keywords: Europe; European integration; the idea of Europe

\begin{abstract}
European integration has exerted a profound effect on contemporary idea of Europe. This paper tries to analyze first the background and cause then the detail of European integration, with the purpose of concluding its influence on the idea of Europe in the final part.
\end{abstract}

\section{Introduction}

European integration is the dawn of a new Europe; it has since then exerted profound influence on contemporary idea of Europe. It also represents a new development in the evolution of the idea of Europe. To say about European integration, there is great necessity to mention its origins and causes imbedded in 19th and 20th nationalism and the consequent conflicts broke out in the continent as well as the following two world wars and the cold war.

The rise of nationalism and the increasing threat of conflicts in 19th and 20th century made European thinkers and political elites seek to ensure peace and stability by fostering a sense of unity between European nations. Originally, nationalism was a " conscious bound shared by a group of people who feel strongly attached to a particular land and who possess a common language, culture and history marked by shared glories and sufferings----like a religion, nationalism provides the individual with a sense of community and with a cause worthy of self-sacrifice." [1] The essential components of modern nationalism emerged during the French Evolution; the Romantic Movement also awakened nationalist feelings. The Napoleonic wars kindled nationalist sentiments in the German states. Nevertheless, the embryo of nationalism was conceived in the German uprising against Napoleon in 1813. However, since the end of 19th century, gradually the irrational mythical quality of nationalism intensified. It evolved into "Chauvinism and Militarism and finally into its extreme----imperialism, which means evasion and exploration of other nations by those European great powers." [2] Like a scholar ever remarked.

By kindling deep love for the past, including a longing for ancient borders, glories and power, nationalism would lead to wars of expansion. By arousing the emotions to fever pitch, nationalism would shatter rational think, drag the mind into a world of fantasy and myth, and introduce extremism into politics. Love of nation would become an overriding passion threatening to extinguish the liberal ideals of reason, freedom and equality.

This is the very cause when nationalism evolved into imperialism in the 19th and 20th century and consequently conflicts rose between European nations. Therefore, European intellectual elites sought to promote the idea of European unification through cohesion and cooperation to ensure peace between the warring nations of Europe.

\section{Causes of Integration}

Contemporary ideas of Europe and Europeanness are deeply imbued with the horrors of the two world wars. In the 2nd decade of the 20th century, nation states were fueled by an explosive nationalism and were grouped into alliances that faced each other with ever-mounting hostility. It was this environment of uncertainty, and political and economic instability, coupled with the ideological conflict between fascism, commercialism and democratic liberalism that lead to the way 
to a new conflict to be fought in European soil. Many young Europeans hold the war as a celebration; they repeated, "better war this eternal waiting" for a bitter and desperate hope. However, the 1st world war brought great losses, disasters and misery for the mass, the mood of disillusionment gripped the soldiers in the trenches. Many people thought that western civilization has lost its spiritual center. They recognized the horror and brutality of war, with the hope that war would never happen. [3] However, their will was in vain, the 2nd war broke out only 21 years after the first world war. Similar to the 1st world war, it was a nightmare bringing sad memories and spiritual hurt to people. Many scholars and intellectuals picked up their pen to criticize war and call for peace and stability.

The idea of Europe that was generated from the destruction caused by two major conflicts in the span of about 30 years is one that fostered interdependence and acknowledged the shift in social, political and economic power across the Atlantic. The lessons of the wars and the international order that has emerged from those conflicts are the most important point for the understanding of the idea of Europe [4]. It is in the framework of postwar European reconstruction that it is possible to witness the re-emergence of the idea of Europe based on unity and cooperation.

Another effect of the Second World War was the seemingly final division between east and west within geographical Europe. This leads to the cold war, without open conflict but featured by political, economic and ideological struggle. It is another reason contributing to European integration post-war. The difference of social system and ideology are the roots of the cold war, which leads to the division of the continent between western and Eastern Europe, the so-called "iron curtain" marked the physical and metaphorical boundaries of the new social and political order. During this period, 1 in order to avoid the ever present challenge of recurring Chauvinism and nationalism, and to foster a sense of unity, as well as to create a bulwark against Bolshevism, a policy of formal economic and political-military cooperation between the states of non-communist Europe did indeed seem the best solution. Thus, Western Europe went on its slow way to form a community following some of the leads provided by the many plans formulated in previous centuries. [5]. While Eastern Europe states were becoming increasingly more isolated from economic and political relations with the rest of Europe. So here the writer mainly talks about the integration of Western Europe. As to the period of Cold War, the purpose of Western European integration is to prevent further conflict between Western European states and to ensure that Western Europe was adequately protected from the advance of communism.

At the beginning of 1990s, the USSR disintegrated and communism failed in Eastern Europe, the Cold War came to an end. Then Western Europe last its rivalry from Eastern part and the threat of USSR. Subsequently Eastern Europe returned to Europe. The EU acceptance and membership of a sizable number of central and eastern European states marked the re-admission of Eastern Europe to contemporary idea of Europe. European integration then enlarged and enhanced.

\section{European Integration}

European integration embodies in such aspects as economic, political and cultural, etc. As to economic integration, the European Community/Single Market should be firstly mentioned. It is part of a greater whole of European Union; it is one of the most recent developments in the process of European integration, it is by far the most widely studied European project because it has developed hand in hand with the consolidation of economic cooperation. [6].

The launch of the Euro has crucial significance. It is mow becoming the symbol of economic Europe. Another two should be covered here are the European Free Trade Organization (EFTA) and the European Economic Area (EEA). The former is often defined as a custom union, but actually it is a conglomeration of disparate political interests and systems, while the latter mainly aims at promoting a greater degree of cooperation between EFTA and EU members and extends the four basic freedoms (freedom of movement of people, goods, service and capital) to non-EU members.

In a word, economic cooperation must rise to the challenge of globalization and the competition in international markets to ensure the future feasibility of economic cooperation of Europe. 
[7]Economic Europe, particularly embedded in European Union, is at the heart of the contemporary idea of Europe.

Political integration mainly consists of aspects of security, defense, foreign policy and social and human rights as well as development. Various approaches of cooperation embody the process of political integration. What should be mentioned under this topic are the European Union (EU), the Council of Europe (CE), and the North Atlantic Organization (NATO), the Organization for Security and Cooperation (OSCE) and WEU. The EU can assert itself as the biggest supranational organization to unify Europe and also the most comprehensive idea of political Europe thus far. The $\mathrm{CE}$ was one of the first western European political organization that Eastern Europe gained access to. Thus it was an invaluable actor in the process of transition and eased the return of Eastern Europe to Europe. Moreover, the focus on human rights and democracy through the rule of law has provided the foundation for cooperation between European states. [8]

The two crucial issues that emerge from political Europe are intergovernmentalism and supranationalism. To sum up, EU can be regarded as the most powerful and coherent idea of political Europe.

As to social and cultural integration, there is much to say about it. The significance of the social idea of Europe should be separate from the state and state relations. European social and cultural spaces have an important impact on the creation of the idea of Europe. The process of European integration is a vehicle for creating a European social and cultural space. The Council of Europe and the EU, especially the EU, play the most proactive role in social and cultural discourses, in order to create a social and cultural dimension to promote popular support and involvement in the process of European integration.

\section{Influence on the idea of Europe}

The challenge to the concept of nation-state. The concept of nation is the basis of the idea of Europe in 18th century embodied in the Enlightenment movement. While the Process of European integration has been seen as a move towards post-national Europe. Some kind of organized/federal entity replaces the nation/state as a basic unit in national and international politics. The differentiation of society along multicultural lines and the processes of globalization are undermining both the internal and external sovereignty of the existing nation states.

Since then, with the power of community slowly growing, the defense of nation-state by Euro-pessimists is waged more strongly than ever. [9] Those who express their skepticism about the attempts to reach more in-depth integration may well fight a rearguard action as to the sovereignty of states. Also we should be wary to holdup the nation states, which is not centuries old but a fairly recent construction, a created tradition. It is quite interesting to note that in many cases, the nation-state is not as strong as has been thought. It is a much older concept, with a mainly regional cultural identity seems to hide behind it.

External Exclusion. It indicates the process of being excluded from the idea of Europe. The progressive development of the process of European integration has had significant impact on the opportunities of migration and movement for EU citizens. This weakens the internal border within Europe, while increases the scrutiny and control of external frontiers. The so-called Fortress Europe that strengthens the physical and metaphorical barriers erected against the external world enhances the division between the rights of EU nationals and third-country nationals. This kind of external exclusion highlights the impact of power hierarchies on contemporary idea of Europe.

Us/other dichotomy. In the post world war era, the onset of European cooperation under the banner of EEC provides the basis for a new phase in European history. The achievement of political stability and economic prosperity in Western Europe had its own price, that is the creation of the eastern European Other due to the distinction in social system and ideology between the two sides of the "Iron Curtain." 
At the end of the Cold War when the USSR disintegrated into sizable countries adopting a brand new social system, Eastern Europe returned to the idea of Europe. The non-European nations return to Europe's other. EU citizens regard themselves the US and the third-country nationals as well as the European Muslims the Other. The 9.11 terrorist attack highlights the resentment and antagonism from the Other.

\section{Summary}

The idea of Europe is still based upon the division between the US and the Other. The process of exclusion is therefore the main feature of the idea of Europe and is thus what Europe identity is based upon.

\section{References}

[1]Marvin. Perry, An Intellectual History of Modern Europe( Houghton Mifflin Company,1992), p.239.

[2]Roberta. Guerrina: Europe: History, Ideas and Ideologies (Hodder Headline Group, London 2002), p.48

[3]Xiuyu, Zeng, The Evolution of Western civilization ( Inner Mongolia Publishing House, Hohehot 2003), p.288.(In Chinese)

[4] Ibid.[2], p.49.

[5]Peter. Rietbergen: Europe--- A Cultural History (London and New York, Routledge Press1998), P. 430.

[6] Ibid.[2], p.103.

[7] Ibid.[2], p.113.

[8] Ibid.[2], p.99.

[9] Ibid.[5], P. 431. 